\title{
PROFIL SENSORI PRODUK MSG PT. X DENGAN VARIASI MEDIA AIR MINERAL DAN KALDU AYAM
}

\section{Sensory Profile of MSG in PT. X with Mineral Water and Chicken Broth Media Variations}

\author{
Devi Farisa Maulidiah*, Kiki Fibrianto \\ Jurusan Teknologi Hasil Pertanian, FTP Universitas Brawijaya Malang \\ Jl. Veteran, Malang 65145 \\ *Penulis Korespondensi, Email: devifmaulidia@gmail.com
}

\begin{abstract}
ABSTRAK
Analisis sensori merupakan analisis yang menggunakan indera manusia sebagai instrumennya. PT. X salah satu perusahaan yang memproduksi monosodium glutamate (MSG). PT. X ingin mengetahui karakteristik sensori produknya dengan menggunakan analisis sensori. Penelitian ini bertujuan untuk mengetahui karakteristik sensori produk akhir MSG PT. X. Metode yang digunakan yaitu quantitative descriptive analysis (QDA) dengan variasi media pelarut air mineral dan kaldu ayam. Dari penelitian ini terdapat 9 karyawan yang menjadi panelis terlatih. Atribut MSG yang dilarutkan dalam air mineral yaitu menghasilkan rasa umami, aftertaste umami dengan intensitas lebih rendah daripada dilarutkan dengan kaldu ayam, meningkatkan mouthfeel getir, menghasilkan mouthfeel menyebar, dan tidak menghasilkan aftertaste manis. MSG yang dilarutkan dalam kaldu ayam meningkatkan rasa umami, aftertaste umami, menurunkan mouthfeel getir, menghasilkan aftertaste manis tetapi tidak menghasilkan mouthfeel menyebar.
\end{abstract}

Kata kunci: Atribut, MSG, Panelis

\begin{abstract}
Sensory analysis is an analysis that uses the human senses as an instrument. $P T . X$ is one of the companies that produce monosodium glutamate (MSG). PT. X wants to know the sensory characteristics of the product using sensory analysis. This study aims to determine the sensory characteristics of the final product of MSG PT. X. The method used is quantitative descriptive analysis (QDA) with a variety of solvent media in mineral water and chicken broth. From this study there were 9 employees who were trained panelists. The attributes of MSG dissolved in mineral water are producing umami taste, lower intensity umami aftertaste than dissolved in chicken broth, increasing bitter mouthfeel, producing diffuse mouthfeel, and not producing a sweet aftertaste. MSG dissolved in chicken broth increases umami taste, umami aftertaste, decreases bitter mouthfeel, produces a sweet aftertaste but does not produce diffuse mouthfeel.
\end{abstract}

Keywords: Attributes, MSG, Panelists

\section{PENDAHULUAN}

PT. X salah satu perusahaan yang memproduksi monosodium glutamate (MSG). MSG merupakan garam glutamat yang berfungsi sebagai flavor enhancer yang ditambahkan ke dalam makanan menyediakan fungsi penyedap seperti glutamat bebas (Yamaguchi \& Ninomiya, 2000). Selain analisis kimia, fisik, dan biologi PT. X ingin menjaga kualitas produknya dengan menggunakan analisis sensori. 
Menurut SNI 01-2346-2006, pengujian sensori merupakan cara pengujian menggunakan indera manusia sebagai alat utama untuk menilai mutu produk. Atribut yang dinilai meliputi mutu kenampakan, bau, rasa, dan konsistensi/ tekstur serta beberapa faktor lain yang diperlukan untuk menilai produk tersebut. Pengujian sensori mempunyai peranan penting sebagai pendeteksian awal dalam menilai mutu untuk mengetahui penyimpangan dan perubahan produk.

Sebelum aplikasi analisis sensori lebih lanjut, PT. X memerlukan gambaran profil sensori produk akhirnya serta membentuk tim panelis terlatih terlebih dahulu. Salah satu metode sensori yang tepat digunakan untuk mendeskripsikan sensori produk pangan yaitu metode Quantitative Descriptive Analysis (QDA).

Penelitian ini menggunakan analisis sensori metode QDA dengan variasi pelarut air mineral dan kaldu ayam. Pengujian sensori menggunakan metode QDA menggunakan panelis terlatih. Adapun pelaksanaan dari penelitian ini yaitu rekrutmen, seleksi, pelatihan panelis, dan evaluasi. Hasil dari penelitian ini diperoleh profil sensori MSG PT. X yang dilarutkan dalam air mineral dan kaldu ayam.

\section{BAHAN DAN METODE}

\section{Bahan}

Bahan yang digunakan yaitu monosodium glutamate (MSG) small crystal, MSG fine crystal, MSG powder, air minum dalam kemasan merk "maaqo", kaldu ayam kampung, asam sitrat, asam cuka, gula, garam, kafein, guanosine monophospat (GMP).

Alat

Cup plastik bening, sendok plastik, plastik klip ukuran $3 \times 5 \mathrm{~cm}$, spidol, kertas label, tissue, beaker glass, labu ukur, timbangan analitik.

\section{Metode Penelitian}

Metode yang digunakan yaitu analisis sensori metode quantitative descriptive analysis (QDA) dengan variasi media pelarut air mineral dan kaldu ayam.

\section{Prosedur Analisis}

\section{Seleksi Panelis}

Perekrutan panelis dilakukan kepada karyawan PT. X. Karyawan yang bersedia mengikuti akan melangsungkan tahap seleksi meliputi wawancara, pengisian kuisioner dan uji sensitivitas.

\section{a. Wawancara}

Calon panelis akan diseleksi melalui pengisian kuisioner dan wawancara. Wawancara mengenai ketertarikan, kebersediaan dan kesehatan. Kemudian calon panelis akan diminta untuk mengisi form kesediaan untuk menjadi panelis dengan mengikuti seluruh rangkaian penelitian dari awal hingga akhir.

\section{b. Uji rasa dasar dan aroma}

Bahan uji rasa dasar disajikan dalam bentuk larutan yaitu Larutan gula (1\%, 2\%), larutan garam $(0.12 \%, 0.8 \%)$, larutan asam sitrat $(0.01 \%, 0.05 \%)$, larutan kafein $(0.01 \%, 0.05 \%)$, larutan MSG $(0.05 \%)$, air mineral larutan disajikan kedalam cup plastik sebanyak $\pm 30 \mathrm{ml}$. Untuk aroma dasar gula pasir, raw sugar, tetes tebu, dan asam cuka disajikan dengan meneteskannya pada permukaan kapas, lalu panelis menuliskan responnya dalam kuisioner. 


\section{Pelatihan Panelis}

\section{a. Uji Ambang Mutlak}

Larutan gula $(0.5 \%, 1 \%, 2 \%, 4 \%, 8 \%)$, larutan garam $(0.04 \%, 0.08 \%, 0.16 \%, 0.32 \%$, $0.64 \%)$, larutan asam sitrat $(0.01 \%, 0.02 \%, 0.04 \%, 0.08 \%, 0.16 \%)$, larutan kafein $(0.015 \%$, $0.03 \%, 0.06 \%, 0.12 \%, 0.24 \%)$, larutan MSG (0.007\%, 0.014\%, 0.028\%, 0.056\%, 0.112\%). Sampel disajikan kedalam cup plastik sebanyak $\pm 30 \mathrm{ml}$. Panelis diminta untuk mencicip sampel yang disediakan lalu penilaian dilakukan dengan memberikan tanda (+) apabila mendeteksi rasa, serta tanda (-) apabila tidak mendeteksi rasa pada sampel., lalu respon panelis dituliskan pada kuisioner.

\section{b. Uji Pembeda}

Larutan MSG $(0.014 \%)$ dan larutan GMP (0.005\%) disajikan kedalam cup plastik sebanyak $\pm 30 \mathrm{ml}$. Terdapat 3 sampel yang terdiri dari 2 sampel sama dan 1 sampel berbeda tetapi dengan konsentrasi yang sama. Panelis diminta untuk mencicip sampel yang disediakan lalu penilaian dilakukan dengan memberikan tanda $(\sqrt{ })$ pada kolom kuisioner. Pengujian ini menggunakan sampel flavor enhancer yang berbeda yaitu Monosodium Glutamate (MSG) dan Guanosine Monophospat (GMP).

\section{c. Focus Group Discussion (FGD)}

Larutan MSG powder (0.02\%), larutan MSG fine crystal $(0.02 \%)$, larutan MSG small crystal $(0.02 \%)$ disajikan kedalam cup plastik $\pm 30 \mathrm{ml}$. Panelis mencicipi larutan tersebut yang kemudian memberikan responnya secara individu kedalam kuisioner. Lalu, masing-masing panelis menyuarakan pendapatnya pada sesi diskusi yang dipimpin oleh panel leader.

\section{d. Uji Intensitas}

Kosakata standar hasil FGD, kemudian perlu didefinisikan dengan definisi verbal atau standar referensi dan titik skala untuk intensitas yang disepakati. Sampel untuk atribut rasa dan aftertaste umami (larutan MSG $0.014 \%, 0.028 \%, 0.056 \%$, dan $0.112 \%$ ), atribut rasa dan aftertaste asin (larutan garam $0.040 \%, 0.080 \%, 0.160 \%$, dan $0,300 \%$ ), atribut rasa dan aftertaste manis (larutan gula $1 \%, 2 \%, 4 \%$, dan $8 \%$ ), atribut tetes tebu (tetes tebu 1, 2, 4, 8 tetes), atribut manis legit (raw sugar $5 \mathrm{~g}, 10 \mathrm{~g}, 15 \mathrm{~g}, 20 \mathrm{~g}$ ), atribut manis (gula $5 \mathrm{~g}, 10 \mathrm{~g}, 15,20 \mathrm{~g}$ ), atribut asam (asam cuka 1, 2, 4, 8 tetes). Panelis menilai intensitas dengan memberikan tanda "titik" pada garis skala yang tersedia pada kuisioner.

\section{Evaluasi Sensori}

Sampel yang digunakan pada evaluasi sensori yaitu larutan MSG powder $(0.03 \%$; $0.04 \%$; $0.05 \%)$, larutan MSG fine crystal (0.03\%; 0.04\%; 0.05\%), larutan MSG small crystal $(0.03 \%$; $0.04 \% ; 0.05 \%)$. Larutan kaldu + MSG powder (0.03\%; 0.04\%; 0.05\%), larutan kaldu + MSG fine crystal (0.03\%; 0.04\%; 0.05\%), larutan kaldu + MSG small crystal (0.03\%; 0.04\%; 0.05\%). Serbuk kering MSG powder, MSG fine crystal, MSG small crystal. Evaluasi sensori dilakukan dengan menggunakan kosakata standar serta menilai intensitasnya seperti yang dilakukan pada uji intensitas yaitu dengan memberikan tanda "titik" pada garis skala yang tersedia di kuisioner. Pengujian dilakukan hingga sesuai dengan yang diharapkan. Hasil dari uji coba evaluasi ini dinilai oleh pemimpin panel, lalu setelah yakin hasilnya dapat dipercaya dan diulang kemudian penilaian yang sebenarnya dapat dilakukan. Data hasil uji kemudian dianalisis secara statistik.

\subsection{Analisis Data}

Data uji rasa dasar dianalisis menggunakan tabulasi dan frekuensi yang ditampilkan melalui grafik individual plot. Uji threshold dianalisis menggunakan Best Estimate Threshold (BET) menggunakan Excel 2013. Uji segitiga dianalisis menggunakan tabulasi dan frekuensi menggunakan Excel 2013 yang dibandingkan dengan tabel binomial. Uji skala dianalisis menggunakan Paired T-test dan Pearson correlation menggunakan perangkat lunak minitab 17 
yang ditampilkan melalui grafik scatterplot. Uji kuantitatif (QDA) dianalisis secara statistik menggunakan General Linear Model (GLM) dengan perangkat lunak Minitab 17.

\section{HASIL DAN PEMBAHASAN}

\section{Analisis Kimia Kaldu Ayam}

Tabel 1. Hasil analisis Kimia Kaldu Ayam

\begin{tabular}{|c|c|c|c|c|c|}
\hline No & Jenis uji & $\begin{array}{l}\text { Pengujian } \\
\text { ke- }\end{array}$ & Satuan & Hasil & Metode \\
\hline 1 & Protein & $\begin{array}{l}1 \\
2 \\
3\end{array}$ & $\begin{array}{l}\% \\
\% \\
\%\end{array}$ & $\begin{array}{l}2.75 \\
3.43 \\
2.91\end{array}$ & $\begin{array}{c}\text { AOAC/981.10/OMUDK.129, } \\
\text { Kjeldahl }\end{array}$ \\
\hline 2 & Lemak & $\begin{array}{l}1 \\
2 \\
3\end{array}$ & $\begin{array}{l}\% \\
\% \\
\%\end{array}$ & $\begin{array}{l}9.78 \\
9.81 \\
9.91\end{array}$ & 18-8-5/MU/SMM-SIG, Weilbull \\
\hline 3 & $\mathrm{Na}$ & $\begin{array}{l}1 \\
2 \\
3\end{array}$ & $\begin{array}{l}\mathrm{Mg} / 100 \mathrm{ml} \\
\mathrm{Mg} / 100 \mathrm{ml} \\
\mathrm{Mg} / 100 \mathrm{ml}\end{array}$ & $\begin{array}{l}16.88 \\
16.71 \\
16.56\end{array}$ & 18-8-5/MU/SMM-SIG, ICP-OES \\
\hline
\end{tabular}

\section{Rekrutmen dan Seleksi}

Sebanyak 26 karyawan tetap QC dan 8 karyawan QA terdapat 17 orang bersedia di wawancara. Dari hasil wawancara diketahui bahwa sebanyak 2 orang berjenis kelamin perempuan dan 15 orang laki-laki. 15 orang berasal dari daerah Jawa Timur dan 2 orang berasal dari daerah Sulawesi Selatan. Sebanyak 15 orang berpendidikan terakhir SMA, 1 orang D1, dan 1 orang sarjana. Sebanyak 6 orang menyukai makanan kombinasi rasa asin, gurih, manis, 4 orang menyukai rasa asin gurih, 2 orang menyukai rasa asin gurih dengan sensasi pedas, sedangkan panelis lain memilih netral. Sebanyak 5 orang tidak menyukai makanan berbau amis dan rasa pahit, 3 orang tidak menyukai kuah kental, sedangkan panelis lainnya memilih netral. Sebanyak 4 orang merupakan perokok berat, 2 orang perokok sedang, sedangkan panelis lainnya tidak merokok. Setelah proses wawancara, terdapat 15 karyawan yang bersedia mengikuti pengujian selanjutnya. Sebanyak 10 orang berhasil menjawab $80 \%$ benar untuk uji rasa dasar, dan 11 orang untuk uji aroma dasar.

\section{Pelatihan Panelis}

\section{a. Uji Ambang Mutlak}

Tabel 2. Hasil Uji Ambang Mutlak

\begin{tabular}{cc}
\hline Atribut & BET Grup (\%) \\
\hline Umami & 0.014 \\
Manis & 0.597 \\
Asin & 0.078 \\
Pahit & 0.016 \\
Asam & 0.013 \\
\hline
\end{tabular}


Nilai BET grup untuk rasa umami yaitu sebesar $0.014 \%$, nilai BET grup untuk rasa manis yaitu sebesar $0.597 \%$, nilai BET grup untuk rasa asin yaitu sebesar $0.078 \%$, nilai BET grup untuk rasa pahit yaitu sebesar $0.016 \%$, dan nilai BET grup untuk rasa asam yaitu sebesar $0.013 \%$, sehingga diperoleh nilai BET grup tiap atribut yang beragam. Atribut rasa asam memiliki nilai BET terendah dibandingkan dengan nilai atribut rasa lainnya yaitu sebesar $0.013 \%$, artinya panelis memiliki kepekaan yang tinggi terhadap rasa asam dibandingkan dengan rasa lainnya. Sedangkan atribut rasa manis memiliki nilai BET tertinggi dibandingkan dengan atribut rasa lainnya yaitu sebesar $0.597 \%$, artinya sensitivitas panelis lebih rendah terhadap rasa manis dibandingkan dengan rasa lainnya sehingga membutuhkan konsentrasi yang lebih tinggi untuk merasakan rasa manis.

\section{b. Uji Segitiga}

Panelis yang melakukan uji pembeda yaitu sebanyak 12 orang. Sedangkan 3 orang calon panelis ID 12, 16, dan 17 tidak bersedia mengikuti rangkaian uji selanjutnya. Dari 12 panelis terdapat 9 orang panelis yang mampu membedakan sampel.

\section{c. Focus Group Discussion}

Panelis memberikan respon secara individu kedalam kuisioner, yang kemudian menyuarakan persepsinya melalui forum diskusi yang dipimpin panel leader. Hasil diskusi yang disepakati akan digunakan untuk uji.

Tabel 3. Hasil Focus Group Discussion

\begin{tabular}{ll}
\hline \multicolumn{1}{c}{ Atribut } & \multicolumn{1}{c}{ Definisi } \\
\hline Rasa manis & Rasa manis gula tebu \\
Rasa asin & Rasa asin garam \\
Rasa umami & Rasa umami MSG \\
Aftertaste manis & Rasa manis di akhir \\
Aftertaste asin & Rasa asin di akhir \\
Aftertaste umami & Rasa umami di akhir \\
Aroma manis seperti raw sugar & Manis legit \\
Aroma manis seperti tetes tebu & Manis sangat legit sedikit gosong \\
Aroma manis tebu & Manis gula tebu \\
Aroma asam & Asam seperti cuka \\
Mouthfeel getir & Gurih sedikit bergetar di lidah \\
Mouthfeel menyebar & Menyebar diseluruh permukaan lidah \\
\hline
\end{tabular}

\section{d. Uji Intensitas}

Tabel 4. Hasil Konsistensi Uji Intensitas

\begin{tabular}{lcccccccc}
\hline \multicolumn{1}{c}{ Atribut } & PCC & PCC & PCC & PCC & Paired & Paired & Paired & Paired \\
\hline Rasa umami & $\mathbf{1}$ & $\mathbf{2}$ & $\mathbf{3}$ & $\mathbf{4}$ & $\mathbf{1}$ & $\mathbf{2}$ & $\mathbf{3}$ & $\mathbf{4}$ \\
Rasa asin & 0.676 & 0.496 & 0.689 & 0.441 & 0.530 & 0.126 & 0.018 & 0.094 \\
Rasa manis & 0.944 & 0.953 & 0.670 & 0.536 & 0.540 & 0.500 & 0.239 & 0.262 \\
Aftertaste & & & & 0.822 & 0.557 & 0.069 & 0.154 & 0.128 \\
umami & 0.605 & 0.735 & 0.848 & 0.936 & 0.600 & 0.663 & 0.233 & 0.407 \\
Aftertaste asin & 0.858 & 0.544 & 0.887 & 0.640 & 0.777 & 0.731 & 0.963 & 0.620
\end{tabular}




\begin{tabular}{lcccccccc} 
& PCC & PCC & PCC & PCC & Paired & Paired & Paired & Paired \\
\multicolumn{1}{c}{ Atribut } & $\mathbf{1}$ & $\mathbf{2}$ & $\mathbf{3}$ & $\mathbf{4}$ & $\mathbf{1}$ & $\mathbf{2}$ & $\mathbf{3}$ & $\mathbf{4}$ \\
\hline Aftertaste manis & $*$ & 0.354 & 0.841 & 0.913 & 0.000 & 0.500 & 0.069 & 0.044 \\
Aroma gula & & & & & & & & \\
pasir & 0.465 & 0.741 & 0.669 & 0.765 & 0.056 & 0.199 & 0.077 & 0.020 \\
Aroma asam & 0.664 & 0.814 & 0.917 & 0.891 & 0.827 & 0.136 & 0.636 & 0.500 \\
\hline K
\end{tabular}

Keterangan : PCC untuk 9 panelis $=0.666$. $\mathrm{P}$ value paired $\mathrm{t}$-test $>0.05$

PCC 1 = nilai pearson correlation konsentrasi 1 , dst . Paired $1=$ nilai paired t-test konsentrasi 1 , dst

"panelis tidak memberikan respon

Data hasil pengujian dianalisis secara statistik menggunakan Pearson correlation dan Paired T-Test. Nilai batas kritis (PCC) dengan taraf signifikansi $5 \%$ untuk 9 orang panelis yaitu 0.666. Sedangkan $p$-value untuk Paired $T$-Test jika $>0.05$ menandakan panelis secara individu telah konsisten dalam memberikan respon penilaian intensitas.

\section{e. Uji Utama}

Tabel 5. Hasil ANOVA General Linear Model

\begin{tabular}{lccc}
\hline Atribut & $\begin{array}{l}\text { Jenis } \\
\text { Larutan }\end{array}$ & Jenis Kristal & Jenis Konsentrasi \\
\hline Rasa umami & $0.044^{*}$ & 0.106 & 0.276 \\
Rasa manis & 0.118 & 0.122 & 0.107 \\
Rasa asin & 0.482 & 0.763 & $0.014^{*}$ \\
Aftertaste umami & $0.002^{*}$ & 0.154 & $0.012^{*}$ \\
Aftertaste asin & 0.525 & 0.876 & $0.001^{*}$ \\
Aftertaste manis & $0.000^{*}$ & 0.401 & 0.350 \\
Mouthfeel getir & $0.003^{*}$ & 0.225 & $0.007^{*}$ \\
Mouthfeel & $0.000^{*}$ & 0.891 & 0.277 \\
menyebar & - & 0.176 & - \\
Aroma tetes & - & 0.085 & - \\
Aroma asam & - & 0.949 & - \\
Aroma raw sugar & - & 0.647 & - \\
Aroma gula & \multicolumn{2}{c}{} \\
\hline \multicolumn{2}{r}{ Keterangan = ${ }^{*}$ Berbeda nyata } & &
\end{tabular}

Respon panelis pada pengujian setiap atribut kemudian ditabulasi dan dianalisis menggunakan General Linear Model (GLM). Hasil beda nyata pada GLM yaitu atribut yang memiliki $P$-value $<0.05$ kemudian diuji lanjut menggunakan uji Fisher untuk mengetahui atribut berpengaruh nyata. 


\section{Atribut sensori yang berbeda nyata}

\section{a. Rasa umami}

Tabel 6. Pengaruh Jenis Larutan pada Atribut Rasa Umami

\begin{tabular}{ccccc}
\hline Atribut & Jenis Larutan & P-value & Rerata & Grouping \\
\hline Rasa Umami & Kaldu ayam + MSG & 0.044 & 3.99 & $\mathrm{~A}$ \\
& Air mineral + MSG & & 3.19 & $\mathrm{~B}$ \\
\hline
\end{tabular}

Rasa umami disebabkan adanya asam glutamate bebas pada MSG yang bereaksi dengan reseptor di lidah. Resepetor di lidah yang bertanggung jawab dalam memberikan rasa umami yaitu mGluR1, mGliR4 dan T1R1+T1R3 (Kurihara, 2015). Asam glutamate pada MSG akan meningkatkan rasa umami pada makanan terutama yang memiliki kandungan protein. Protein pada makanan akan meningkatkan rasa umami akibat proses pemasakan sehingga akan memecah protein menjadi asam-asam amino bebas. Menurut International Food Information Council Foundation (IFIC) ketika dalam bentuk bebas dan tidak terikat oleh asam amino lain, glutamate dapat memberikan efek flavor enhancer pada makanan. MSG yang dilarutkan kedalam kaldu memiliki nilai rerata lebih tinggi dibandingkan jika dilarutkan kedalam air mineral. Hal tersebut diduga karena adanya penambahan asam glutamat bebas yang berasal dari kaldu ayam. Menurut hasil uji laboratorium di PT. Maxzer Solusi Steril, kaldu ayam kampung memiliki kandungan protein sebesar $3.03 \%$.

\section{b. Rasa asin}

Tabel 7. Pengaruh Jenis Konsentrasi pada Atribut Rasa Asin

\begin{tabular}{ccccc}
\hline Atribut & Jenis Konsentrasi (\%) & P-value & Rerata & Grouping \\
\hline Rasa Asin & 0.04 & 0.014 & 3.47 & A \\
& 0.05 & & 3.29 & A \\
& 0.03 & & 2.04 & B \\
\hline
\end{tabular}

Rasa asin pada monosodium glutamate disebabkan adanya ion $\mathrm{Na}^{+}$pada monosodium glutamate. Ion bebas $\mathrm{Na}^{+}$yang bereaksi dengan reseptor lidah inilah yang diduga berkontribusi dalam memberikan rasa asin pada MSG. Menurut Bartoshuk (1980) ion natrium memiliki tanggung jawab dalam pembentukan rasa asin. Akan tetapi rasa asin yang dihasilkan setiap garam memiliki intensitas yang berbeda-beda seiring meningkatnya ion negatif (anion) pada molekul tersebut (Henney, 2010). Sehingga garam glutamate (MSG) dengan garam klorida $(\mathrm{NaCl})$ memiliki rasa asin meskipun dengan intensitas yang berbeda. Respon panelis terhadap rasa asin pada MSG menunjukkan bahwa terdapat kenaikan intensitas setiap penambahan konsentrasi MSG seiring meningkatnya kandungan garam pada larutan meskipun pada konsentrasi $0.04 \%$ memiliki rerata lebih besar dibandingkan dengan konsentrasi $0.05 \%$, akan tetapi keduannya masih memiliki notasi yang sama.

\section{a. Aftertaste umami}

Tabel 8. Pengaruh Jenis Larutan pada Atribut Aftertaste Umami

\begin{tabular}{ccccc}
\hline Atribut & Jenis Larutan & P-value & Rerata & Grouping \\
\hline \multirow{2}{*}{ Aftertaste Umami } & Kaldu ayam + MSG & 0.002 & 4.31 & A \\
& Air mineral + MSG & & 2.96 & B \\
\hline
\end{tabular}


Aftertaste umami pada larutan monosodium glutamate diduga karena adanya sisa-sisa larutan kaldu ayam dengan asam glutamate yang tidak larut dalam saliva. Kaldu ayam mengandung lemak yang non polar sedangkan saliva bersifat polar. Komponen saliva terdiri dari 99\% air dan mengandung beberapa elektrolit (natrium, kalium, kalsium, klorida, magnesium, bikarbonat dan fosfat) dan protein (Gregio, 2014). Diduga lemak tidak larut saliva yang terkandung dalam kaldu ayam, sesuai dengan hasil laboratorium yang dilakukan oleh PT. Maxzer Solusi Steril menunjukkan bahwa kandungan lemak pada kaldu ayam kampung yaitu sebesar 9,83\% sehingga menyebabkan larutan kaldu ayam dengan MSG tertahan lebih lama dilidah sehingga menyebabkan adanya aftertaste.

Tabel 9. Pengaruh Jenis Konsentrasi pada Atribut Aftertaste Umami

\begin{tabular}{ccccc}
\hline Atribut & Jenis Konsentrasi (\%) & P-value & Rerata & Grouping \\
\hline Aftertaste Umami & 0.05 & 0.012 & 4.46 & $\mathrm{~A}$ \\
& 0.03 & & 3.51 & $\mathrm{AB}$ \\
& 0.04 & & 2.94 & $\mathrm{~B}$ \\
\hline
\end{tabular}

Aftertaste dari senyawa umami umumnya lebih kuat dari senyawa sensasi lainnya karena afinitas senyawa umami terhadap reseptor (Wijaya, 2009). Menurut Umami Information Center, suatu studi sensori dilakukan oleh panelis dengan mencicipi larutan glutamat, inosinat, garam meja, dan asam tartarat. Setelah itu panelis diminta untuk menilai aftertaste dengan meludahkan larutan yang telah dicicip dan membandingkan intensitas rasa yang tersisa di mulut. Hasil penelitian tersebut diketahui bahwa panelis merasakan rasa umami meninggalkan aftertaste selama beberapa menit jika dibandingkan rasa lain yang telah memudar (Yamamoto, 2015).

\section{b. Aftertaste Asin}

Tabel 10. Pengaruh Jenis Konsentrasi pada Atribut Aftertaste Asin

\begin{tabular}{ccccc}
\hline Atribut & Jumlah Konsentrasi (\%) & P-value & Rerata & Grouping \\
\hline Aftertaste asin & 0.04 & 0.01 & 2.70 & A \\
& 0.05 & & 1.71 & B \\
& 0.03 & & 0.94 & B \\
\hline
\end{tabular}

Aftertaste asin diduga disebabkan adanya ion natrium pada monosodium glutamat yang masih tersisa di reseptor lidah. Menurut Bartoshuk (1980) ion natrium memiliki tanggung jawab dalam pembentukan rasa asin. Jumlah konsentrasi yang diberikan pada panelis tidak menunjukkan respon yang linear, hal ini diduga dipengaruhi oleh konsentrasi MSG yang dibawah ambang pengenalan aftertaste panelis maupun persepsi panelis yang belum konsisten.

\section{c. Aftertaste manis}

Tabel 11. Pengaruh Jenis Larutan pada Atribut Aftertaste Manis

\begin{tabular}{ccccc}
\hline Atribut & Jenis larutan & P-value & Rerata & Grouping \\
\hline Aftertaste manis & Kaldu ayam + MSG & 0 & 0.64 & $\mathrm{~A}$ \\
& Air mineral + MSG & & 0 & $\mathrm{~B}$ \\
\hline
\end{tabular}

Diduga aftertaste manis yang terdeteksi disebabkan terdapat senyawa yang lebih kompleks seperti protein, karbohidrat, lemak, dan mineral. Berdasarkan hasil uji laboratorium PT.Maxzer Solusi Steril kaldu ayam memiliki kandungan protein sebesar 3.03\%, lemak 9.85\%, 
natrium $16.71 \mathrm{mg} / 100 \mathrm{ml}$ dan kalsium sebesar $9.56 \mathrm{mg} / 100 \mathrm{ml}$. Menurut USDA, jumlah karbohidrat pada kaldu ayam yaitu sebesar $18 \mathrm{~g} / 100 \mathrm{~g}$.

\section{d. Mouthfee/ Getir}

Tabel 12. Pengaruh Jenis Larutan pada Atribut Mouthfeel Getir

\begin{tabular}{ccccc}
\hline Atribut & Jenis Larutan & P-value & Rerata & Grouping \\
\hline Mouthfeel getir & Air mineral + MSG & 0.003 & 2.36 & $\mathrm{~A}$ \\
& Kaldu ayam + MSG & & 1.12 & $\mathrm{~B}$ \\
\hline
\end{tabular}

Mouthfee/getir yang dirasakan panelis lebih dominan pada MSG yang dilarutkan ke dalam air mineral saja diduga karena tidak ada komponen lain selain MSG yang menghalangi ataupun menutupi mouthfeel asli dari MSG. Menurut Gillette (1985), MSG tidak hanya memberikan rasa saltiness dan fullness atau murni seperti $\mathrm{NaCl}$ akan tetapi juga memberikan bitter (getir) atau metallic. Selain itu, diduga kaldu ayam memiliki kandungan yang lebih kompleks seperti adanya lemak, karbohidrat dan protein yang dapat menyamarkan mouthfee/ getir sehingga menimbulkan mouthfeel lain seperti berlemak, berminyak dan kental.

Tabel 13. Pengaruh Jenis Konsentrasi pada Atribut Mouthfee/ Getir

\begin{tabular}{ccccc}
\hline Atribut & Jenis Konsentrasi (\%) & P-value & Rerata & Grouping \\
\hline Mouthfeel getir & 0.04 & 0.007 & 2.61 & $\mathrm{~A}$ \\
& 0.05 & & 1.60 & $\mathrm{~B}$ \\
& 0.03 & & 1.02 & $\mathrm{~B}$ \\
\hline
\end{tabular}

Mouthfeel getir terdeteksi disetiap konsentrasi dengan respon tertinggi pada konsentrasi $0.04 \%$ yang diduga pada konsentrasi $0.04 \%$ panelis telah mencapai ambang batas mouthfeel getir sehingga pada konsentrasi diatas $0.04 \%$ panelis tidak dapat mendeteksi kenaikan pada konsentrasi tersebut. Ambang batas yaitu ambang dimana panelis sudah tidak dapat merasakan peningkatan intensitas ketika konsentrasinya ditingkatkan (Delwiche, 2009).

\section{e. Mouthfee/ Menyebar}

Tabel 14. Pengaruh Jenis Larutan pada Atribut Mouthfeel Menyebar

\begin{tabular}{ccccc}
\hline Atribut & Jenis Larutan & P-value & Rerata & Grouping \\
\hline Mouthfeel menyebar & Air mineral + MSG & 0.003 & 2.86420 & $\mathrm{~A}$ \\
& Kaldu ayam + MSG & & 0 & $\mathrm{~B}$ \\
\hline
\end{tabular}

Menurut Umami Information Center, umami sering digambarkan sebagai rasa yang "menyebar dan melapisi keseluruh lidah", yang sesuai dengan percobaan yang dilakukan di area lidah menunjukkan bahwa rasa manis dan asin lebih intens dirasakan di ujung lidah sementara umami dirasakan diseluruh area lidah (Yamamoto, 2015). Selain itu, berdasarkan hasil uji laboratorium PT. Maxzer Solusi Steril kandungan lemak pada sampel kaldu ayam sebesar $9.85 \%$. Kandungan lemak yang terdapat pada kaldu ayam tersebut diduga mempengaruhi viskositas dari larutan, sehingga larutan kaldu ayam + MSG memiliki mouthfeel yang kental dan mengurangi bahkan menghilangkan mouthfeel menyebar. 


\section{SIMPULAN}

Penelitian ini menunjukkan bahwa MSG yang dilarutkan dalam air mineral menghasilkan atribut sensori rasa umami, rasa asin, aftertaste umami, aftertaste asin, mouthfeel getir dan mouthfeel menyebar, sedangkan pada MSG yang dilarutkan dalam kaldu ayam terdeteksi aftertaste manis tetapi tidak terdeteksi mouthfeel menyebar.

\section{DAFTAR PUSTAKA}

Bartoshuk LM. 1980 Sensory Analysis of the Taste of NaCl Biological and Behavioral Aspects of Salt Intake. Kaere MR, Fregly MJ, Bernard RA,

Delwiche, J. 2009. The Sensory Evaluation of Dairy Products. Springer science business media. The Ohio State University. Colombus

Gillette, M. 1985. Flavor Effects of Sodium Chloride. Dalam Reducing salt in Foods. 2007. Sciencedirect topic monosodium glutamate.

Gregio, A.M.T. 2014. Saliva Composition and Functions: A Comprehensive Review. The Journal of Contemporary Dental Practice. www.thejcdp.com.

Henney, J. E. 2010. Strategies to Reduce Sodium Intake in the United States. Institute of Medicine of the National Academies. The National Academies Press: Washington, D.C. www.nap.edu.

Kurihara, K. 2015. Umami the Fifth Basic Taste: History of Studies on Receptor Mechanisms and Role as a Food Flavor. BioMed Research International. Hindawi Publishing Corporation. Aomori University. Japan

SNI 01-2346-2006. Petunjuk Pengujian Organoleptik dan atau Sensori. Badan

USDA. 2018. Food Composition Databases. NDB Id 06080 Soup, chicken broth or bouillon, dry. https://ndb.nal.usda.gov

Wijaya, H.C. 2009. Sensasi Rasa. Food Review. Institut Pertanian Bogor.

Yamaguchi, S \& Ninomiya, K. 2000. Umami and Food Palatability. J.Nutr. 130:921S926S

Yamamoto, T. 2015. Umami. www.umamiinfo.com. Tokyo, Japan. Standarisasi Nasional 